\title{
Rethinking Islamic Economics
}

\author{
Mansor Haji Ibrahim \\ Professor, International Centre of Education in Islamic Finance (INCEIF), \\ Malaysia
}

\begin{abstract}
The emergence of Islamic viewpoints on economic issues under the umbrella of Islamic economics has captivated much interest especially in its practical manifestation in Islamic banking and finance. In light of the failure of mainstream economics to address many pressing issues, and hence the need for alternative views, this paper offers assessments of Islamic economics whether (i) it is relevant to this need, (ii) it has progressed to the extent that it has been made to become relevant, and (iii) it is also in need of reform. While I argue that Islamic economics is relevant, it falls short of expectations on the second issue. The major reasons being: (a) the lack of progress in Islamic economics theory, (b) the similarity of Islamic economic practices in the forms of Islamic finance to conventional finance, and (c) its limited ability thus far to embrace multi-perspective views. On the basis of these, I conclude that Islamic economics is also in need of reform.
\end{abstract}

Keywords: Islamic Economics, Islamic worldview, Reform.

JEL Classification: A2, B59, P41, P43

KAUJIE Classification: F13, G1, H1, L0 


\section{Introduction}

Islamic economics is now recognized as a distinct discipline. It has emerged out of discontent with the existing conventional economic system and of aspirations to have an alternative system that is in consonance with Islamic laws or the Sharī'ah. At the heart of Islamic economics is the Islamic worldview, the conception of reality and set of beliefs derived from the teachings of Islam.

Islamic economists have long debated the flaws of mainstream economic views shaped mainly by neoclassical economics. Indeed, Islamic economists are not alone in the call for relooking at or even rejecting economics from the neoclassical lens. As the lead paper to this discussion forum by Jack Reardon (2019) rightly emphasizes, mainstream economics has failed to adapt to fast-changing economic environments and bring solutions to emerging and pressing economic problems. We need alternative economic views. We need a pluralistic approach to economics. We need to reform our economics education.

My purpose here is not to re-iterate these key points but to look at Islamic economics, which offers alternative views and solutions to economic problems. More specifically, I discuss the relevance of Islamic economics and whether it is also in need of a reform. In doing so, I first briefly state the Islamic worldview. Taking this as a point of departure and in light of Reardon's lead paper, I answer the following questions: Is Islamic economics relevant? Has it been made relevant? Is it in need of reform?

\section{The Islamic Worldview}

A worldview refers to the conception of reality and set of beliefs that influence one's perception and thought of the world and actions that one takes. The Islamic worldview is the worldview founded on the teachings of Islam with the Holy Qur'ân and the sayings (ahāalith) of the Prophet (may the peace and blessings of Allah be upon him) serving as primary sources. It is based on three fundamental principles or concepts: (i) the concept of tawhid, (ii) the concept of $k h i l a \overline{f a h} /{ }^{\prime} a b d$, and (iii) concept of al-dìn.

The concept of tawhìd covers the unity of Allah Almighty in Lordship, the unity of Allah's names and attributes, and the unity of Allah Almighty in worship. Allah Almighty is the sole Creator of all things, seen and unseen. He alone is the Provider and the Sustainer. All attributes of Allah Almighty that $\mathrm{He}$ talks of Himself - the Cherisher, the Sustainer, the Merciful, the All-Hearing, the All-Knowing, the Omniscient, the Omnipotent and others - belong only to Allah Almighty alone. Since all creations belong to Him alone, man must submit to Him alone in worships and he must not associate anyone and anything with Him. Man must act and perform duties in all aspects of life in conformity with His directions and guidance as encapsulated in the Holy Qur'ān and elaborated in the ahāalith of the Prophet (may the peace and blessings of Allah be upon him).

In all aspects of life including economic life, man must be conscious at all times of the presence of Allah Almighty. Man is created and placed on this earth as vicegerent (khaliffah) and servant (' $a b d$ ). The two are inseparable as lucidly described by Haneef (1997):

While the role of khalifah implies that nature, the universe, and other creations, are entrusted to man for his utilization, the role of 'abd means that man does not have any independent authority or absolute rights other than to follow the will of God. Both these roles have to be lived simultaneously and any neglect of either one would not enable man to function as his true self. (p. 45)

The concept of khiläfah/'abd makes it clear that man possesses no absolute ownership in whatever he possesses. As khalïfah, he is given trust (amānah) to utilize what he has at his disposal in the best way for the benefits of himself as well as of others, in accordance with Allah's will. In doing so, he must always be conscious that he is a servant who submits to and obeys only Allah Almighty.

To Muslims, Islam is a complete way of life or aldin. In Islam, there is no demarcation between "religious" life and worldly life. All actions are acts of worship to Allah Almighty when (i) they are conducted in manners prescribed and allowed by Islam and (ii) in them obedience and submission to Allah Almighty is demonstrated. Man must carry his life as prescribed by Islam to fulfill obligations and trust given to him. There are many obligations that man must perform. One obligation that is pertinent to the 
economic life of man is to establish justice ('adālah) on earth. Allah Almighty provides guidance and barometers of justice through His Divine Revelation, the Holy Qur'ān, and through the life examples and sayings of His prophet (may the peace and blessings of Allah be upon him).

In a nutshell, the Islamic worldview or the conception of reality that governs the perception, thinking, and actions of the life of Muslims, is the belief that all creations belong to Allah Almighty and he must utilize them in the best way and as a manifestation of worship to Allah Almighty in accordance with His will and guidance such that justice is established. The Islamic worldview means that Islam is a complete way of life and that it directs all spheres of activities, including economic activities.

\section{Islamic Economics Alternative: Is It Relevant?}

Economics provides a framework for understanding and predicting outcomes as a result of human economic interactions, in great part to aid impact assessment of events and policies and formulation of policies to influence outcomes. The mainstream economics approaches this based on the core beliefs of individualism, optimization, and equilibrium. In the world of no market frictions of all sorts, driven by self-interest, the optimization behavior of economic agents leads to the maximum welfare for society. Through the invisible hand, the system adjusts itself. Thus, not surprisingly, neoclassical economics advocates non-intervention and policy initiatives, if any, should be directed toward erasing market frictions such that the economy can function properly.

In looking at economic problems, I am quite fortunate to be trained not only from the lens of neoclassical economics but also from the perspectives of institutional economics. From these, I believe that we must avail ourselves at the outset with different ways of looking at economic issues. We may even place at the side-line the utopian world of the neoclassical economics since it may lead us to nowhere. Institutional economics informs us that proper understanding of the economic system must not be devoid of institutions that govern economic transactions. North $(1987,1989)$ defines institutions as formal laws, rules and regulations, enforcement mechanisms, and informal rules that constraint our behavior. From these perspectives, economic outcomes might be different from the ones predicted by mainstream economics. As much as I benefit from institutional economics in understanding economic phenomena, I come to believe that diverse views are a blessing in our quest to resolve emerging economic problems.

Islamic economics brings different core beliefs and principles. Instead of individualism, collective wellbeing supersedes individual interest. The pursuit of individual interest, while allowed, must not be to the detriment of society. In Islamic economics, property rights are never absolute. Looking from these lenses, Islamic economics obviously offers alternative views and, hence, it is relevant.

\section{Islamic Economics: Has It Been Made Relevant?}

A key milestone in the emergence of Islamic economics as a discipline was the $1^{\text {st }}$ international conference on Islamic economics held in Makkah in 1976, which drew a large number of scholars to discuss economic issues facing Muslims during the period. The conference covered a wide range of issues including the state of Islamic economics, Islamic economics education, the state's roles (zakāh and fiscal policy) in an Islamic economic system, Islamic finance, and particularly Islamic banking and takäful, and other topics.

After the Makkah conference, the discourses on Islamic economics became vibrant in ensuing conferences and forums. The early discussions, especially during late 1970s and early 1980s, focused on Islamic economic principles and theories. Unfortunately, the theoretical discussion has dissipated over time and more focus has been given to Islamic finance, which arguably is the manifestation of Islamic economics in practice. Despite being the fastest growing segment of the global financial scene, Islamic banking, since its inception, has always been seen by some with skeptical eyes that it is not markedly different from conventional banking. The doubt over the Islamicity of Islamic banks has led to the following questions in academic circles: "Islamic banking: interest-free or interest-based?" (Chong \& Liu, 2009); "How 'Islamic' is Islamic banking?" (Khan, 2010); "Can Islamic banking ever become Islamic?" (Azmat, Skully, \& Brown, 2015). A similar tone can also be heard in popular and professional circles: "How Shariacompliant is Islamic banking?" (Foster, 2009); "Is Islamic banking really Islamic?" (Aslam, 2012); “Are 
Islamic banks really interest-free?" (Anuar, Mohamad, \& Shah, 2016). In short, to some, Islamic finance fails to offer a solution to the ailing problems of the conventional financial system.

An increasing number of universities offer degrees in Islamic economics and later in Islamic finance. There are several observations that I can make. The study of Islamic economics still falls within the ambit of mainstream economics. Students are normally given the foundations of economics from the neoclassical lens. Although Islamic economics brings new core beliefs and, hence, an alternative approach and perspectives with the break in its theoretical developments, Islamic economics offers mostly the conceptualization of how the economy should work. Hence, it tends to take a back seat to the more rigorous neoclassical framework. Adding to this, at the empirical front, Islamic economics and Islamic finance research frame the analysis within existing theories. As Narayan and Phan (2019, p. 493) note, while this can be acceptable at the early stage of research, we need to start looking at the outset at Islamic economics or Islamic finance from its own lens.

Although Islamic economics should be welcomed for bringing a new perspective, however, it has not adequately acknowledged multi-perspectives to economic issues. A look at Islamic economics degrees reveals that, apart from being within the ambit of neoclassical economics, they are content heavy. Students are overloaded with all kinds of Islamic economics related courses with little room given to the views emerging from economics education reform movements. Even within the Islamic economics, the exposure to various Islamic schools of thought is not adequate. Above all, Islamic economics tends to bring an "all or nothing" tenet in its prescription normally with such statement as "solutions to all problems are in Islamic economics". This seems to be antithesis to the pluralistic view of economics education.

\section{Conclusion: Is Islamic Economics in Need of Reform?}

From the discussion above, and as a conclusion, my answer to the question as to whether Islamic economics is in need of reform is obvious. It is unequivocally yes. The manifestation of Islamic economics in the present Islamic finance seems to portray more of a convergence to the prevailing financial system than being distinct, despite the clear-cut differences in the core beliefs. It seems that Islamic economics is simply economics dressed with values and ethics, which is not alien to the conventional framework. As Ariff (2014) points out, in the context of Islamic banking and finance, it is time that Islamic finance graduates from being Sharī ah-compliant, which he refers to as the modification of existing conventional finance to make it in conformity with Sharīah principles, to being Sharīah-based. This is what I believe for Islamic economics. It should not be based on the modification of mainstream economics to make it Islamic. It should start from its core beliefs. Obviously, the challenge is to proceed from the starting point.

Islamic economics also must recognize the multifaceted nature of an economic system and hence should be open to the multi-perspectives of any economic issue. It should be recognized that the economy comprises of not only individual economic agents but also of institutions and society that formally and informally govern economic interactions and transactions. While Islamic economics emphasizes collective welfare, it also emphasizes that there must be justice and fairness for both individuals and society. While this is at the root of Islamic economics, it should welcome views and inputs from various perspectives in resolving the conflicts that may arise from these interactions and providing solutions to problems arising from economic interactions. At present, Islamic economics not only falls short in providing alternative views, but also has not embraced multi-perspectives to economic issues, at least to the level that I expect. 


\section{References}

Anuar, K., Mohamad, S., \& Shah, M. E., (2016, May 5). Are Islamic banks really interest-free? Asian Investor. Retrieved from: https://bit.ly/2LLWKZq

Ariff, M. (2014). Whither Islamic banking? The World Economy, 37(6), 733-746.

Aslam. (2012, April 4). Is Islamic banking really Islamic? Pakistan Insider. Retrieved from: https://bit.ly/ 2LLXa1W

Azmat, S., Skully, M., \& Brown, K. (2015). Can Islamic banking ever become Islamic? Pacific-Basin Finance Journal, 34, 253-272.

Chong, B. S., \& Liu, M.-H. (2009). Islamic banking: Interest-free or interest-based? Pacific-Basin Finance Journal, 17(1), 125-144.

Foster, J. (2009, December 11). How Sharia-compliant is Islamic banking? $B B C$ News. Retrieved from: http://news.bbc.co.uk/2/hi/business/8401421.stm

Haneef, M. A. (1997). Islam, the Islamic world view and Islamic economics. IIUM Journal of Economics and Management, 5(1), 39-65.
Khan, F. (2010). How 'Islamic' is Islamic banking? Journal of Economic Behavior \& Organization, 76(3), 805-820.

Narayan, P. K., \& Phan, D. H. B. (2019). A survey of Islamic banking and finance literature: issues, challenges and future directions. Pacific-Basin Finance Journal, 53, 484-496.

North, D. C. (1989). Institutions and economic growth: An historical introduction. World Development, 17(9), 1319-1332.

North, D. C. (1987). Institutions, transaction costs and economic growth. Economic Inquiry, 25(3), 419-428.

Reardon, J. (2019). Dialogue on Reform in Mainstream Economics and its Implications for the Islamic Economics Discipline. Journal of King Abdulaziz University: Islamic Economics, 32(2), 61-75.

Mansor Haji Ibrahim is currently a professor and Deputy President Academic and Dean at the International Centre for Education in Islamic Finance (INCEIF), Malaysia. He received his $\mathrm{PhD}$ in Economics in 1996 from Washington University in St. Louis. Prior to INCEIF, he had served at the International Islamic University Malaysia and at Universiti Putra Malaysia. His areas of interest include monetary/macroeconomics, economic development, financial markets analysis, Islamic banking and finance, and applied econometrics. His recent research focuses on the socio-economic implications of institutions and Islamic banking performance. He has been serving as a guest editor for the Pacific-Basin Finance Journal special issues in Islamic finance from 2014 till present and as Associate Editor for Economic Modelling. Throughout his academic career, he has published in various scholarly journals and conducted applied econometrics training on basic econometrics, time series econometrics, and panel data modelling for various institutions.

E-mail: mansorhi@inceif.org 


\section{إعادة التفكيرفي الاقتصياد الإسلامي \\ منصور ماجي إبراهيم \\ أستاذ، المركز الدولي للتعليم في التمويل الإسلامي(INCEIF)}

المستخلص. أثار ظهور وجهات نظر إسلامية حول القضايا الاقتصادية من منظور الاقتصاد الإسلامي

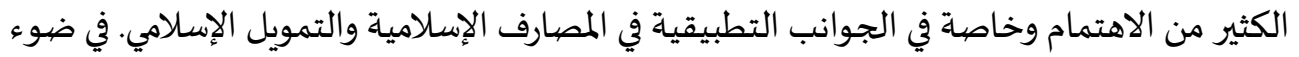

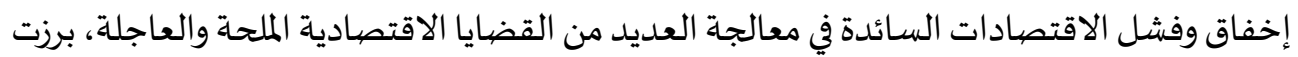

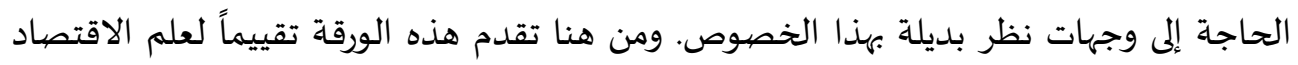

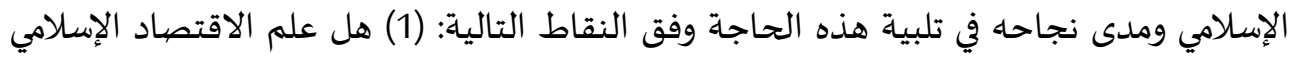

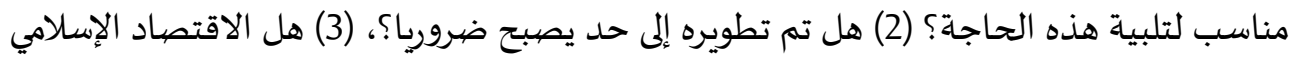

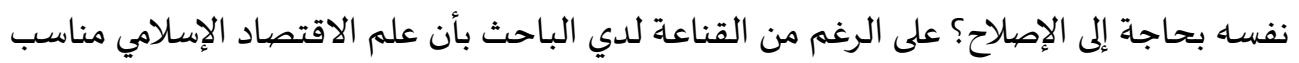

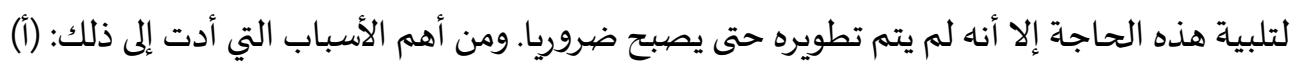

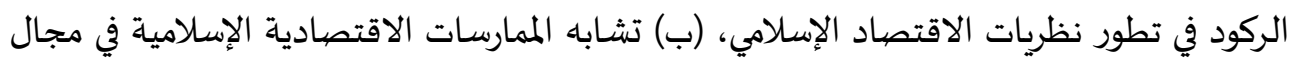

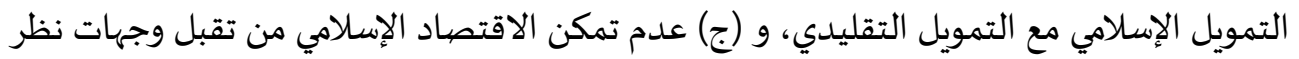
مختلفة. وفي ضوء ذلك فإن الباحث يرى بأن الاقتصاد الإسلامي نفسه بحاجة إلى الإصلاح. الكلمات الدَّالة: الاقتصاد الإسلامي، النظرة الإسلامية العالمية، إصلاح. تصنيف P43، P41، B59، A2: JEL تصنيف L0، H1، G1،F13 : KAUJIE 